\title{
Catalyst evaluation for oxygen reduction reaction in concentrated phosphoric acid at elevated temperatures
}

Hu, Yang; Jiang, Yiliang; Jensen, Jens Oluf; Cleemann, Lars Nilausen; Li, Qingfeng

Published in:

Journal of Power Sources

Link to article, DOI:

10.1016/j.jpowsour.2017.11.054

Publication date:

2018

Document Version

Peer reviewed version

Link back to DTU Orbit

Citation (APA):

Hu, Y., Jiang, Y., Jensen, J. O., Cleemann, L. N., \& Li, Q. (2018). Catalyst evaluation for oxygen reduction reaction in concentrated phosphoric acid at elevated temperatures. Journal of Power Sources, 375, 77-81. https://doi.org/10.1016/j.jpowsour.2017.11.054

\section{General rights}

Copyright and moral rights for the publications made accessible in the public portal are retained by the authors and/or other copyright owners and it is a condition of accessing publications that users recognise and abide by the legal requirements associated with these rights.

- Users may download and print one copy of any publication from the public portal for the purpose of private study or research.

- You may not further distribute the material or use it for any profit-making activity or commercial gain

- You may freely distribute the URL identifying the publication in the public portal 
Manuscript Number:

Title: Catalyst evaluation for oxygen reduction reaction in concentrated phosphoric acid at elevated temperatures

Article Type: Short Communication

Section/Category: Polymer Electrolyte Membrane Fuel Cells: ENG/APP

Keywords: oxygen reduction, catalyst, half cell, high-temperature, phosphoric acid

Corresponding Author: Dr. YANG HU,

Corresponding Author's Institution: Technical University of Denmark

First Author: YANG HU

Order of Authors: YANG HU; Yiliang Jiang; Jens Oluf Jensen, Prof.; Lars Nilausen Cleemann, Dr.; Qingfeng Li, Prof.

Manuscript Region of Origin: DENMARK

Abstract: Phosphoric acid is the common electrolyte for high-temperature polymer electrolyte fuel cells (HT-PEMFCs) that has the advantages such as enhanced $\mathrm{CO}$ tolerance and simplified heat and water management. The currently used rotating disk electrode technique is limited to tests in dilute solutions at low temperatures and hence is not suitable for catalyst evaluation for HT-PEMFCs. In this study, we have designed and constructed a half-cell setup for ORR catalyst evaluation. By optimization of the hydrophobic characteristics of electrodes and the catalyst layer thickness, ORR activities of typical Pt/C catalysts are successfully measured in concentrated phosphoric acid at temperatures above $1000 \mathrm{c}$. In terms of mass-specific activities, the catalyst exhibits about two times higher activity in the half-cell electrode than that observed in fuel cells, indicating the feasibility of the technique as well as the potential for further improvement of fuel cell electrode performance. 


\title{
Catalyst evaluation for oxygen reduction reaction in concentrated phosphoric acid at elevated temperatures
}

Yang Hu,* Yiliang Jiang, Jens Oluf Jensen, Lars N. Cleemann, Qingfeng Li*

Department of Energy Conversion and Storage, Technical University of Denmark, Kemitorvet 207, DK-2800 Kgs. Lyngby, Denmark.

Corresponding authors: a. Yang Hu, E-mail: yanhu@dtu.dk, Tel.: +45 45252327

b. Qingfeng Li, E-mail: qfli@dtu.dk. Tel.: +45 45252318

\begin{abstract}
:
Phosphoric acid is the common electrolyte for high-temperature polymer electrolyte fuel cells (HT-PEMFCs) that has the advantages such as enhanced CO tolerance and simplified heat and water management. The currently used rotating disk electrode technique is limited to tests in dilute solutions at low temperatures and hence is not suitable for catalyst evaluation for HT-PEMFCs. In this study, we have designed and constructed a half-cell setup for ORR catalyst evaluation. By optimization of the hydrophobic characteristics of electrodes and the catalyst layer thickness, ORR activities of typical $\mathrm{Pt} / \mathrm{C}$ catalysts are successfully measured in concentrated phosphoric acid at temperatures above $100^{\circ} \mathrm{C}$. In terms of mass-specific activities, the catalyst exhibits about two times higher activity in the half-cell electrode than that observed in fuel cells, indicating the feasibility of the technique as well as the potential for further improvement of fuel cell electrode performance.
\end{abstract}

Keywords: oxygen reduction, catalyst, half cell, high-temperature, phosphoric acid 


\section{Introduction}

Thanks to the high energy conversion efficiency and environmentally benign operation, polymer electrolyte membrane fuel cells (PEMFCs) are among the most promising candidates of clean energy conversion technologies.[1-3] Compared to conventional fuel cells based on Nafion membrane with the operation temperature below $100{ }^{\circ} \mathrm{C}$, high temperature (HT) PEMFCs that are operated at 120 $200{ }^{\circ} \mathrm{C}$ has several advantages including much enhanced $\mathrm{CO}$ tolerance, simplified heat and water management, and the capability to integrate with fuel processors. [4-10] Phosphoric acid-doped polybenzimidazole (PBI) membranes are the most commonly used material in HT-PEMFCs.[8, 11] Accordingly, the environment in HT-PEMFC electrodes is significantly different from that in conventional PEMFCs. The widely used rotating disk electrode (RDE) testing is developed for catalyst evaluation in dilute acid solutions (e.g. $0.1 \mathrm{M} \mathrm{HClO}_{4}$ or $0.5 \mathrm{M} \mathrm{H}_{2} \mathrm{SO}_{4}$ ) at room temperature. Such results can hardly give a good indication of the catalyst performance in HT-PEMFCs. Therefore, it is of great importance to develop a fast and efficient approach for catalyst evaluation under conditions more relevant to HT-PEMFC, i.e. in concentrated phosphoric acid at typical temperatures of $130-170{ }^{\circ} \mathrm{C}$.

Theoretically, to measure the activity of an electrocatalyst is simple. A current response at a specific potential needs to be recorded. In practice, however, many factors can affect this process. [12-15] In order to determine the intrinsic activity of a catalyst, the mass transport of relevant species needs to be fast enough, at least at low overpotentials, and the amount of the catalyst involved in the reaction is to be accurately measured. [16] Regarding ORR tests using the RDE technique, the catalyst is first dispersed in a solvent and the mass applied is determined by the volume of the ink. The electrochemical active surface area (ECSA) of Pt/C catalysts can be estimated by conducting hydrogen underpotential deposition or $\mathrm{CO}$ adsorption/oxidation tests. By immersing the catalyst layer in an $\mathrm{O}_{2}$ saturated acidic solution, almost all catalyst particles have good access to the reactants, i.e, oxygen, protons, and electrons.[17] The challenge is the big mass transport resistance from the low solubility of molecular $\mathrm{O}_{2}$ and its small diffusion coefficient in aqueous solutions. In $0.1 \mathrm{M}$ $\mathrm{HClO}_{4}$ at room temperature, for example, they have values of $1.26 \times 10^{-3} \mathrm{~mol} \mathrm{~L}^{-1}$ and $1.93 \times 10^{-5} \mathrm{~cm}^{2}$ $\mathrm{s}^{-1}$, respectively. [18] But this resistance can be corrected by applying the Koutecký-Levich analysis, 
a major reason for the wide application of this technique. In hot concentrated phosphoric acid, however, the RDE technique meets greater challenges. The oxygen solubility in concentrated phosphoric acid is much lower, e.g., $3.8 \times 10^{-4}$ mol L ${ }^{-1}$ in $90 \mathrm{wt} \% \mathrm{H}_{3} \mathrm{PO}_{4}$ at $100{ }^{\circ} \mathrm{C}$ and $2.8 \times 10^{-4} \mathrm{~mol}$ $\mathrm{L}^{-1}$ at $150{ }^{\circ} \mathrm{C}$.[19] And the viscosity of concentrated $\mathrm{H}_{3} \mathrm{PO}_{4}$ is two orders of magnitude higher than that of dilute acid solutions.[20-22] Consequently, oxygen transport is limited and the recorded ORR limiting current is very small. The $\mathrm{O}_{2}$ diffusion resistance within the diffusion and catalyst layer is so significant that it can no longer be compensated by the Koutecký-Levich equation. Fleige et al. have skillfully developed a pressurized RDE setup to increase the oxygen solubility and diffusion rate in electrolytes, which was an effective strategy but it increased the complexity of the measurement and met the issue of unstable reference electrode potentials under the pressurized environment.[23] Construction of an RDE setup operational at temperatures above $100{ }^{\circ} \mathrm{C}$ is another challenge. The tightness of the joint of the electrode disk and the surrounding plastic body is always an issue at elevated temperatures. Few reports are available on RDE tests of catalysts in hot concentrated acid. $[22,24]$

A fuel cell gas diffusion electrode is a porous structure with optimized pore size distribution and wetting characteristics. This also applies to gas diffusion electrodes in half cells. Using gas diffusion electrodes in electrochemical half-cells is attractive for the characterization of the catalyst activity under practical conditions closer to fuel cell operation.[25-31] Zalitis et al.[30] introduced a floating electrode design with a thin catalyst layer, whereby the catalyst activity was measured with efficient mass transport in 4.0 $\mathrm{M} \mathrm{HClO}_{4}$. Pinaud et al. [27] showed a half-cell design with a graphite flow field and the catalyst activity could be accurately measured in $1.0 \mathrm{M} \mathrm{HClO}_{4}$. In order to increase the mass transport and catalyst utilization in gas diffusion electrodes, optimum distribution of electrolyte throughout the catalyst layer is the key. Several mathematical models have been proposed to understand structures of gas diffusion electrodes, which, to some extent, showed good correlation with experimental results.[32, 33]

In this work, we designed and tested an electrochemical half-cell setup for catalyst evaluation in concentrated phosphoric acid at elevated temperatures. By optimization of the hydrophobic characteristics of the electrode and application of a thin catalyst layer, ORR activities of typical 
highly porous catalysts can be measured under conditions of efficient high mass-transport. With a commercial $\mathrm{Pt} / \mathrm{C}$ catalyst as a reference, the obtained activity results by the half-cell setup are comparable with those from the RDE measurements at room temperature and from fuel cell tests at high temperatures, demonstrating the feasibility of this method for catalyst performance evaluation under HT-PEMFC conditions.

\section{Experimental}

\subsection{Half-cell construction and electrochemical test protocols}

The structure of the half-cell setup is illustrated in Figure 1. The cell body was made from a low thermal expansion borosilicate glass (Pyrex $\left.{ }^{\circledR}\right)$, which is resistant to concentrated phosphoric acid till $200{ }^{\circ} \mathrm{C}$.[34] The cell had an oil heating jacket and a polytetrafluoroethylene (PTFE) lid. The jacket was heated by circulating silicone oil through a thermostatic oil bath (JULABO ${ }^{\circledR}$ H10) equipped with a temperature controller (HUBER ${ }^{\circledR}$ Pilot One $202 \mathrm{C}$ ). The local temperature close to the working electrode was monitored by a separate thermocouple. A three-electrode configuration was used in the setup. The reference electrode (RE) was a reversible hydrogen electrode (RHE) with a freshly cleaned platinum wire soaked in the same electrolyte as in the main compartment with constant hydrogen bubbling. The distance between the Luggin capillary tip and the working electrode (WE) surface was about $5 \mathrm{~mm}$ to avoid the shielding effect. [35] A platinum mesh placed facing the WE was used as the counter electrode (CE). The electrolyte was $85 \mathrm{wt} \% \mathrm{H}_{3} \mathrm{PO}_{4}$ (from VMR ${ }^{\circledR}$, ACS reagent grade) or lower concentrations diluted from it with Millipore water. All glassware was thoroughly cleaned by using Piranha solution and rinsed with hot Millipore water several times before use.

The WE consisted of a catalyst layer, a microporous carbon layer (MPL) and a gas diffusion layer (GDL), as illustrated in Figure 1. It was embedded into a specially designed PTFE holder. A commercial MPL/GDL assembly (Freudenberg ${ }^{\circledR} \mathrm{H} 23 \mathrm{C} 2$ ) was chosen and used for the electrode preparation after preliminary tests of different MPL and GDL combinations. A PTFE O-ring with an inner diameter of $7 \mathrm{~mm}$ was used as sealing. This also defined the active surface area of the electrode (i.e., $0.385 \mathrm{~cm}^{2}$ ). On the back side of the GDL, a stainless steel current collector with separate gas 
inlet- and outlet- openings was used to achieve good electronic contact. A low platinum load Pt/C catalyst (20 wt \% Pt/C from Johnson Matthey) was selected as the reference material for all measurements since a major motivation for this work is potentially for evaluation of non-platinum catalysts, which often contain high carbon contents. The working electrode was tilted to an angle of $45^{\circ}$, instead of being placed vertically, so that the possible accumulation of purging gas bubbles on the WE surface could be avoided. The electrodes for tests in concentrated $\mathrm{H}_{3} \mathrm{PO}_{4}$ were prepared with hydrophobic characteristics. The catalyst ink was first prepared by mixing a specific amount of 20 $\mathrm{wt} \% \mathrm{Pt} / \mathrm{C}$ in a mixture of $5 \mathrm{wt} \%$ PTFE dispersion and isopropanol. It was then sprayed onto the MPL/GDL substrate kept at $110{ }^{\circ} \mathrm{C}$. The electrode was eventually heated and kept at $360{ }^{\circ} \mathrm{C}$ in $\mathrm{Ar}$ flow for 20 min to remove the surfactant of the PTFE dispersion and sinter the PTFE in the catalyst layer. Addition of PTFE in the catalyst layer is a necessity for constructing a hydrophobic network, though at expense of blocking some catalytic sites. After preliminary efforts to optimize the PTFE content in the catalyst layer, $10 \mathrm{wt} \%$ PTFE in the catalyst layer (PTFE/PTFE+catalyst) was chosen and used throughout the work. A high accuracy balance with the resolution of $0.001 \mathrm{mg}$ was used to precisely determine the actual catalyst loading. For the tests in $5.0 \mathrm{M} \mathrm{H}_{3} \mathrm{PO}_{4}$, a catalyst layer with no addition of PTFE was attempted. In that case, the catalyst layer was prepared by directly depositing a specific amount of catalyst ink (10 mg $20 \mathrm{wt} \% \mathrm{Pt} / \mathrm{C}$ catalyst in $100 \mu \mathrm{L}$ Milli-Q water and $5.0 \mathrm{~mL}$ isopropanol) onto the MPL and dried in air. The catalyst loading for each test would be specified in the discussion section. Scanning electron microcopy was conducted on a Zeiss EVO MA10 and electrode cross sections were made by a Hitachi E-3500 ion mill.

The half-cell measurements were conducted by using a potentiostat (Versa STAT4, Princeton Applied Research). Tests with $\mathrm{O}_{2}$ at the flow rate of about $20 \mathrm{~mL} \mathrm{~min}^{-1}$ was first conducted. At higher flows, the gas might diffuse through the electrode and form bubble in the electrolyte, which was visible and should be avoided during the measurements. Potential cycling between 0 and $1.0 \mathrm{~V}$ at a scanning rate of $50 \mathrm{mV} \mathrm{S}^{-1}$ was initially used to activate the catalyst layer until the stable performance was achieved. A linear sweep voltammogram at $5 \mathrm{mV} \mathrm{s}^{-1}$ from the open circuit voltage (OCV) to $0.2 \mathrm{~V}$ was subsequently recorded. The solution resistance between the RE and WE was determined by conducting electrochemical impedance spectra (EIS) measurements at OCV. It was $1 \sim 1.5 \Omega$ for different tests in $85 \mathrm{wt} \% \mathrm{H}_{3} \mathrm{PO}_{4}$ at $140{ }^{\circ} \mathrm{C}$. After measurements with saturated $\mathrm{O}_{2}$, the 
gas flow was switched to $\mathrm{N}_{2}$ and the double-layer capacitance current of the electrode was recorded at $5 \mathrm{mV} \mathrm{s}^{-1}$. The recorded ORR currents in all figures have been corrected for the capacitance current and solution resistance. The half-cell measurements were done with an upper-temperature limit of $140{ }^{\circ} \mathrm{C}$ (in contrast to a usual working temperature of a HT-PEMFC of $160{ }^{\circ} \mathrm{C}$ ) to limit dehydration of the phosphoric acid over time.

\subsection{RDE tests.}

For comparison, standard RDE tests were conducted at room temperature. The electrolytes were 0.1 $\mathrm{M} \mathrm{HClO}_{4}$ (prepared from $70 \mathrm{wt} \% \mathrm{HClO}_{4}$, Aldrich, $99.999 \%$ trace metals basis) and $\mathrm{H}_{3} \mathrm{PO}_{4}$ solutions of different concentrations (prepared from $85 \mathrm{wt} \% \mathrm{H}_{3} \mathrm{PO}_{4}, \mathrm{VMR} \circledast$, ACS reagent grade). The electrode was prepared by depositing $10 \mu \mathrm{L}$ of well-dispersed catalyst ink $(5 \mathrm{mg} 20 \mathrm{wt} \% \mathrm{Pt} / \mathrm{C}$ in the mixture of $40 \mu \mathrm{L}$ Milli-Q water, $2460 \mu \mathrm{L}$ formic acid, and $50 \mu \mathrm{L} 5 \mathrm{wt} \%$ Nafion solution) on an RDE $\left(0.196 \mathrm{~cm}^{2}\right.$, Pine Research Instrumentation) and dried in air. This gave the catalyst loading of $20 \mu \mathrm{g}_{\mathrm{Pt}}$ $\mathrm{cm}^{-2}$. The RE and CE were a reversible hydrogen electrode and a graphite rod $(99.995 \%$ trace metals basis), respectively.

\subsection{Fuel cell tests}

Fuel cell tests with the same ORR catalyst (20 wt\% Pt/C from Johnson Matthey) with a platinum loading of $50.0 \mu \mathrm{g}_{\mathrm{Pt}} \mathrm{cm}^{-2}$ were also conducted. The anode was a commercial gas diffusion electrode with a platinum of loading of $1.6 \mathrm{mg}_{\mathrm{Pt}} \mathrm{cm}^{-2}$, supplied from Danish Power Systems ${ }^{\circledR}$. The used membrane was cast from polybenzimidazole of a molecular weight ca. 78000 and doped in 85 wt $\%$ $\mathrm{H}_{3} \mathrm{PO}_{4}$ for a week, reaching an acid doping level of about $10 \mathrm{H}_{3} \mathrm{PO}_{4}$ per repeat unit of the polymer. The membrane electrode assemblies (MEAs) were constructed by sandwiching the membrane between the cathode and anode without pre-hot pressing. The active area of the MEA was $9 \mathrm{~cm}^{2}$. The test was conducted using in-house hardware and fuel cell test setup. Polarization curves were obtained by a current step potentiometry from OCV to $0.2 \mathrm{~V}$ with the steady state potential recorded 2 min after each current was set. EIS measurements at OCV was conducted to measure the fuel cell resistance for the iR-correction. The measurement was carried out at ambient pressure and $140{ }^{\circ} \mathrm{C}$ with hydrogen and oxygen $\left(\mathrm{H}_{2} / \mathrm{O}_{2}\right)$ and no humidification. 


\section{Results and discussion}

We first evaluated the feasibility of the RDE approach for ORR catalyst evaluation in concentrated $\mathrm{H}_{3} \mathrm{PO}_{4}$. Figure 2 shows the ORR polarization curves of a $\mathrm{Pt} / \mathrm{C}$ coated RDE electrode at room temperature in $0.1 \mathrm{M} \mathrm{HClO}_{4}$ and $\mathrm{H}_{3} \mathrm{PO}_{4}$ solutions of different concentrations. The strong effect of phosphate adsorption on the catalyst can be visualized by the negative shift of the kinetic region of ORR curves with switching from the dilute perchloric acid to $0.5 \mathrm{M} \mathrm{H}_{3} \mathrm{PO}_{4}$ and with further increase in the $\mathrm{H}_{3} \mathrm{PO}_{4}$ concentration. Meanwhile, the limiting current decreased significantly due to the decrease in oxygen solubility and diffusion coefficient in concentrated $\mathrm{H}_{3} \mathrm{PO}_{4}$. When tested in $14.8 \mathrm{M}$ (i.e. 85 wt $\%) \mathrm{H}_{3} \mathrm{PO}_{4}$ the electrode exhibited a limiting current of only $0.08 \mathrm{~mA} \mathrm{~cm}_{\text {geo }}{ }^{-2}$, which was even smaller than the double-layer capacitance current of the carbon support. In this case, the mass transport resistance in the catalyst layer was so significant that the Koutecky-Levich equation derived from the flat RDE could no longer be applied anymore.

The half-cell approach was then investigated. The key to a successful catalyst evaluation using the gas diffusion electrode is to achieve fast mass transport and high, if not full, catalyst utilization. Besides the optimization of electrode structures, the catalyst layer thickness is another factor. Figure 1c shows the cross-section SEM image of a typical working electrode with the catalyst loading of $35.4 \mu \mathrm{g}_{\mathrm{Pt}} \mathrm{cm}^{-2}$ and the mean thickness of $3.4 \mu \mathrm{m}$. During RDE tests, the $\mathrm{O}_{2}$ diffusion distance is a function of the thickness of the catalyst layer and the static boundary layer adjacent to it, which alone is estimated to be about $15.4 \mu \mathrm{m}$ for the condition of $0.1 \mathrm{M} \mathrm{HClO}_{4}, 1600 \mathrm{rpm}$, and room temperature.[15, 36] In case of gas diffusion electrodes, the $\mathrm{O}_{2}$ diffusion in the gas phase is much faster than that of dissolved molecules in aqueous solutions, and hence the resistance primarily originates from the diffusion through the electrolyte film distributed within the catalyst layer. In concentrated phosphoric acid, this film can be as thin as about $100 \mathrm{~nm}$.[33] Therefore, the mass transport in gas diffusion electrodes is much more efficient than that in RDE measurements. In the followings, we will compare the results from the half-cell tests with those from the RDE and fuel cell tests. 
The first comparison was made for RDE and half-cell tests in $5.0 \mathrm{M} \mathrm{H}_{3} \mathrm{PO}_{4}$ at room temperature. In this condition, the RDE approach is still feasible and serve as a reference. [37] The same amount of $\mathrm{Pt} / \mathrm{C}$ catalyst $(19.6 \mu \mathrm{g}$ catalyst or $3.92 \mu \mathrm{g} \mathrm{Pt})$ was deposited on the RDE and the half-cell electrode. As shown in Figure 3a, a standard ORR polarization curve was obtained from the RDE test with an onset potential (at $1.0 \mathrm{~mA} \mathrm{mg}_{\mathrm{Pt}}{ }^{-2}$ ) of $0.95 \mathrm{~V}$ and a half-wave potential of $0.80 \mathrm{~V}$. After correction of the mass-transport resistance by the Koutecky-Levich analysis, the obtained RDE kinetic current for the ORR was very close to that directly measured in the half-cell test. This result verifies the reliability of the half-cell approach for catalyst evaluation in this condition, as also shown in other reports.[27, 30]

The second comparison was made between two gas diffusion electrodes tested in $85 \% \mathrm{H}_{3} \mathrm{PO}_{4}$ at 140 ${ }^{\circ} \mathrm{C}$, one having a platinum loading of $10 \mu \mathrm{g}_{\mathrm{Pt}} \mathrm{cm}^{-2}$ with no PTFE and the other having a thicker catalyst layer $\left(22 \mu \mathrm{g}_{\mathrm{Pt}} \mathrm{cm}^{-2}\right)$ with $10 \mathrm{wt} \%$ PTFE. For the electrode without PFTE, the catalyst was severely flooded. As shown in Figure 3b, a peak current of about $2 \mathrm{~A} \mathrm{mg}^{-1} \mathrm{Pt}$ is observed at $0.5 \mathrm{~V}$, indicating significant mass transport limitation of the dissolved oxygen through the concentrated phosphoric acid. Addition of PTFE in the catalyst layer improved the hydrophobicity and the electrode performance was much enhanced, despite the thicker catalyst layer. At the loading of 22 $\mu \mathrm{g}_{\mathrm{Pt}} \mathrm{cm}^{-2}$ with $10 \mathrm{wt} \%$ PTFE, the electrode did not exhibit any limiting current in the tested interval.

Further investigations were made for electrodes at a constant PTFE content but varied catalyst loadings or catalyst layer thicknesses in $85 \mathrm{wt} \% \mathrm{H}_{3} \mathrm{PO}_{4}$ at $140{ }^{\circ} \mathrm{C}$. The results are shown in Figure 4a. As the catalyst loading decreased from $270 \mu \mathrm{g}_{\mathrm{Pt}} \mathrm{cm}^{-2}$ to $20 \mu \mathrm{g}_{\mathrm{Pt}} \mathrm{cm}^{-2}$, corresponding to a catalyst layer thickness from about 26 to $2 \mu \mathrm{m}$, the mass-specific activity of the catalyst (at $0.8 \mathrm{~V}$ ) increased steadily from $40 \mathrm{~mA} \mathrm{mg}_{\mathrm{Pt}^{-1}}{ }^{-1}$ to $133 \mathrm{~mA} \mathrm{mg}_{\mathrm{Pt}^{-1}}{ }^{-1}$ (Figure $4 \mathrm{~b}$ ), indicating the improved mass transport as well as catalyst utilization in thinner catalyst layers. We expected a steady activity of the catalyst when the catalyst loading was falling in a sufficiently low range where appropriate mass transport and high catalyst utilization were achieved. However, this was not realized. When the catalyst loading was decreased from 47 to $22 \mu \mathrm{g}_{\mathrm{Pt}} \mathrm{cm}^{-2}$, the measured activity still showed a further increase by $20 \%$. That means even lower catalyst loadings need to be investigated. These are, however, very challenging to 
achieve with uniform catalyst dispersion and accurate loading determination. Alternatively, other catalysts with a higher platinum-to-carbon ratio should be used. With the $20 \mathrm{wt} \% \mathrm{Pt} / \mathrm{C}$ catalysts, a loading in the range of $20-40 \mu \mathrm{g}_{\mathrm{Pt}} \mathrm{cm}^{-2}$ gave a qualitative evaluation of the catalytic activity. At the loading of $22 \mu \mathrm{g}_{\mathrm{Pt}} \mathrm{cm}^{-2}$, the mass-specific activity of the $20 \mathrm{wt} \%$ $\mathrm{Pt} / \mathrm{C}$ in $85 \mathrm{wt} \% \mathrm{H}_{3} \mathrm{PO}_{4}$ at $140{ }^{\circ} \mathrm{C}$, was 33 and $133 \mathrm{~mA} \mathrm{mg}_{\mathrm{Pt}^{-1}}$ at $0.85 \mathrm{~V}$ and $0.80 \mathrm{~V}$, respectively. These values cannot be compared to values obtained in $\mathrm{HClO}_{4}$ due to the strong phosphate adsorption.

For ORR measurements in hot concentrated $\mathrm{H}_{3} \mathrm{PO}_{4}$, a fuel cell test is another appropriate reference. We conducted both the half-cell and fuel cell tests at the same temperature with similar catalyst loadings, with the result shown in Figure 4c. At 0.75 and $0.70 \mathrm{~V}$, the catalyst

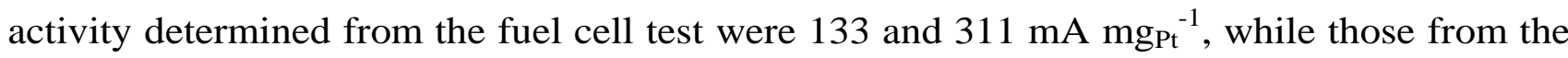
half-cell test were 315 and $836 \mathrm{~mA} \mathrm{mg}_{\mathrm{Pt}^{-1}}{ }^{-1}$, respectively, i.e. about 2.4 times higher. Given the similar conditions in both tests, the enhanced performance is assumed to originate from increased catalyst utilization. It has been estimated that the catalyst utilization in fuel cell electrodes is in some cases only about 20-40\% [38-40]. The observed higher catalytic activity in the half-cell test indicates the possibility of further improvement of the electrode performance in fuel cells.

It should be remarked that to further determine the intrinsic activity of a catalyst, in terms of area-specific or mass-specific activities, it is vital to quantify the electrochemical surface area (ECSA) or the exact catalyst utilization in the catalyst layer. Unfortunately, we haven't found an effective way to fulfill this task. We explored the conventional hydrogen adsorption method and tested the electrode in both $85 \% \mathrm{H}_{3} \mathrm{PO}_{4}$ at $140{ }^{\circ} \mathrm{C}$ and $0.1 \mathrm{M} \mathrm{HClO}_{4}$ at room temperature. The test in $\mathrm{H}_{3} \mathrm{PO}_{4}$ revealed depressed hydrogen adsorption peaks, apparently because of the strongly adsorbed phosphate anions and the temperature dependent feature of hydrogen adsorption on Pt. [41, 42] In $0.1 \mathrm{M} \mathrm{HClO}_{4}$, the electrode was too hydrophobic for this condition and the measured current was extremely small. CO stripping might be a better choice for this task, as Engl et al. [43] have proposed, though factors such as the side reaction 
currents may add challenging to determine the actual $\mathrm{CO}$ oxidation current. Such tests were not carried out in this study.

Apart from the test at $140{ }^{\circ} \mathrm{C}$, the setup developed can also be used to evaluate the catalyst in a wide temperature range. Figure $4 \mathrm{~d}$ shows ORR curves of an electrode $\left(35 \mu \mathrm{g}_{\mathrm{Pt}} \mathrm{cm}^{-2}\right.$ of 20 wt $\% \mathrm{Pt} / \mathrm{C}$ ) at temperatures from 28 to $140{ }^{\circ} \mathrm{C}$. The trend of enhanced ORR kinetics is seen with increasing temperature. Once the ECSA or the catalyst utilization can be measured for each temperature, this provides a means to determine the activation energy of ORR over a wide temperature range.

\section{Conclusions}

Evaluation of ORR electrocatalysts in concentrated phosphoric acid at elevated temperatures by means of the rotating disk electrode technique was shown unsuitable because of the significant mass transport limitation due to the low solubility and diffusion coefficient of oxygen. An electrochemical half-cell setup was designed and constructed for the ORR activity measurement. Gas diffusion electrodes were optimized with respects to the hydrophobic characteristics and catalyst layer thicknesses, allowing a fast evaluation of the catalytic activity of ORR catalysts. Compared with fuel cell electrodes with the same Pt/C catalyst, the half-cell electrode showed about two times higher mass-specific current densities at low overpotentials. This demonstrates the feasibility of the half-cell technique for catalyst evaluation with electrolytes of varied concentration in a wide range of temperatures. The observed higher catalytic activity in the half-cell test indicates the potential for further improvement of the fuel cell electrode performance.

\section{Acknowledgements}

We gratefully acknowledge financial support from the Danish ForskEL program (UPCAT,2015-1-12315) and Innovation Fund Denmark (4M Centre, 12-132710 and NonPrecious, 4106-00012B). 

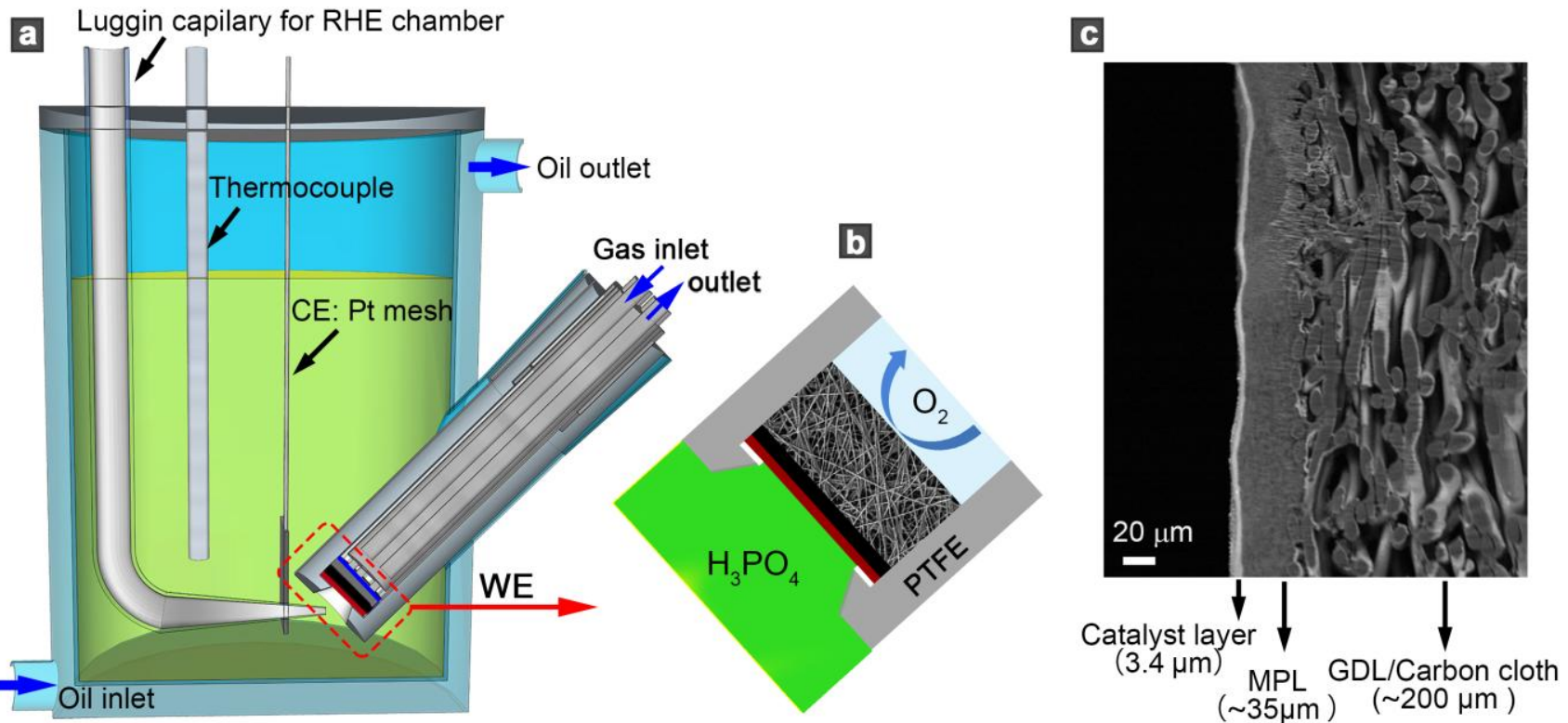

Figure 1: Schematic illustration of the half-cell setup: (a) the overall cross-sectional view, and (b) the structure of the working electrode and the holder. The working electrode comprises a catalyst layer (red), a microporous carbon layer (black) and a supporting carbon cloth. The structure of the current collector was omitted in (b) for clarification. (c) Cross-section SEM image of a typical working electrode, where the catalyst layer consists of $35.4 \mu \mathrm{g}_{\mathrm{Pt}} \mathrm{cm}^{-2}$ of $20 \mathrm{wt} \% \mathrm{Pt} / \mathrm{C}$ and $10 \mathrm{wt} \%$ PTFE.

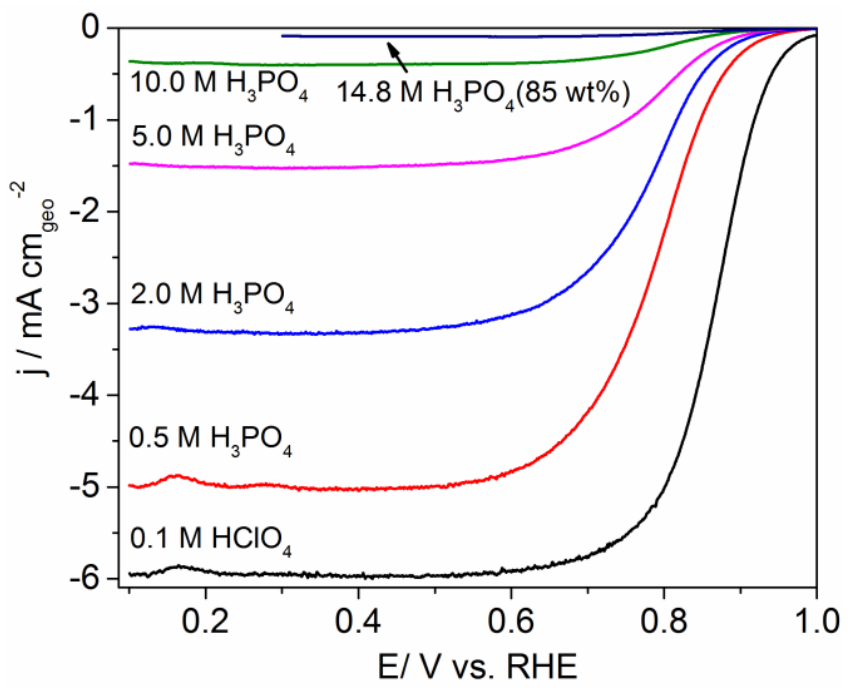


Figure 2: ORR polarization curves of $20 \mathrm{wt} \% \mathrm{Pt} / \mathrm{C}$ by $\mathrm{RDE}$ tests at room temperature in different electrolytes. The catalyst loading was $20 \mu \mathrm{g}_{\mathrm{Pt}} \mathrm{cm}^{-2}$. The RDE rotation speed was $1600 \mathrm{rpm}$. All curves have been corrected for the double-layer capacitance current and solution resistance.
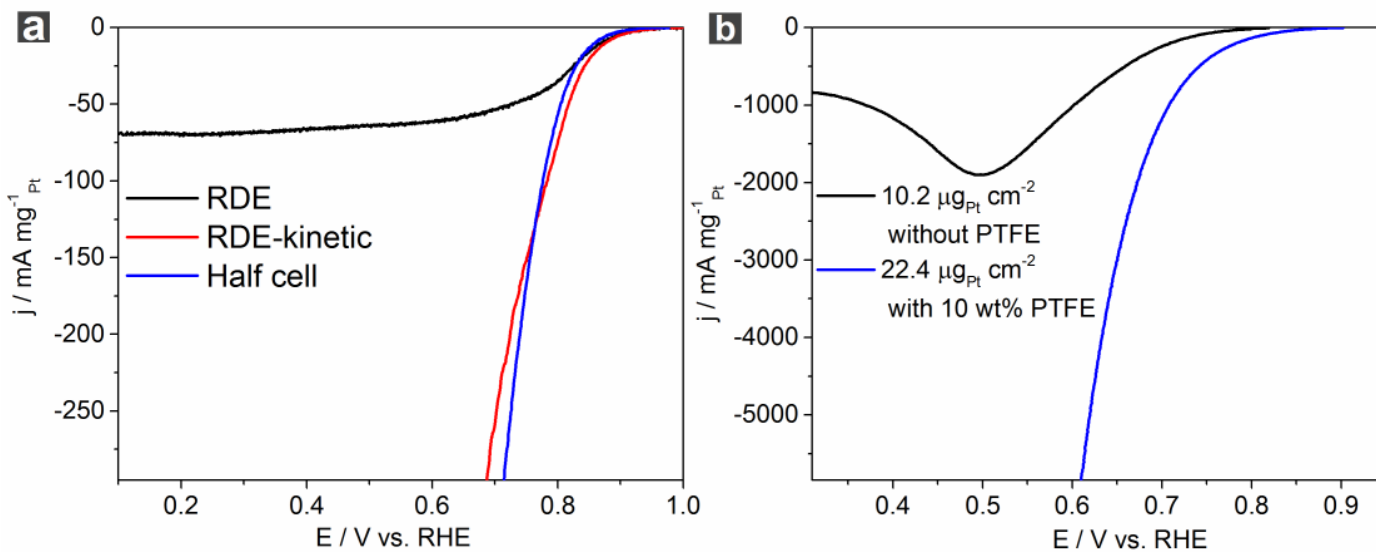

Figure 3: (a) ORR polarization curves of $20 \mathrm{wt} \% \mathrm{Pt} / \mathrm{C}$ in $5.0 \mathrm{M} \mathrm{H}_{3} \mathrm{PO}_{4}$ solution at room temperature by RDE and half-cell tests. The same amount of catalyst was used for both the RDE and the half-cell tests, i.e. $19.6 \mu \mathrm{g}$ catalyst (3.92 $\mu \mathrm{g}$ Pt). The RDE rotation speed was $1600 \mathrm{rpm}$. "RDE" and "RDE-kinetic" refer to the measured ORR current by the RDE test and the mass-transport corrected ORR current by Koutecky-Levich analysis, respectively. (b) ORR polarization curves of two gas diffusion electrodes with or without PFTE from half-cell tests in $85 \% \mathrm{H}_{3} \mathrm{PO}_{4}$ at $140{ }^{\circ} \mathrm{C}$. 

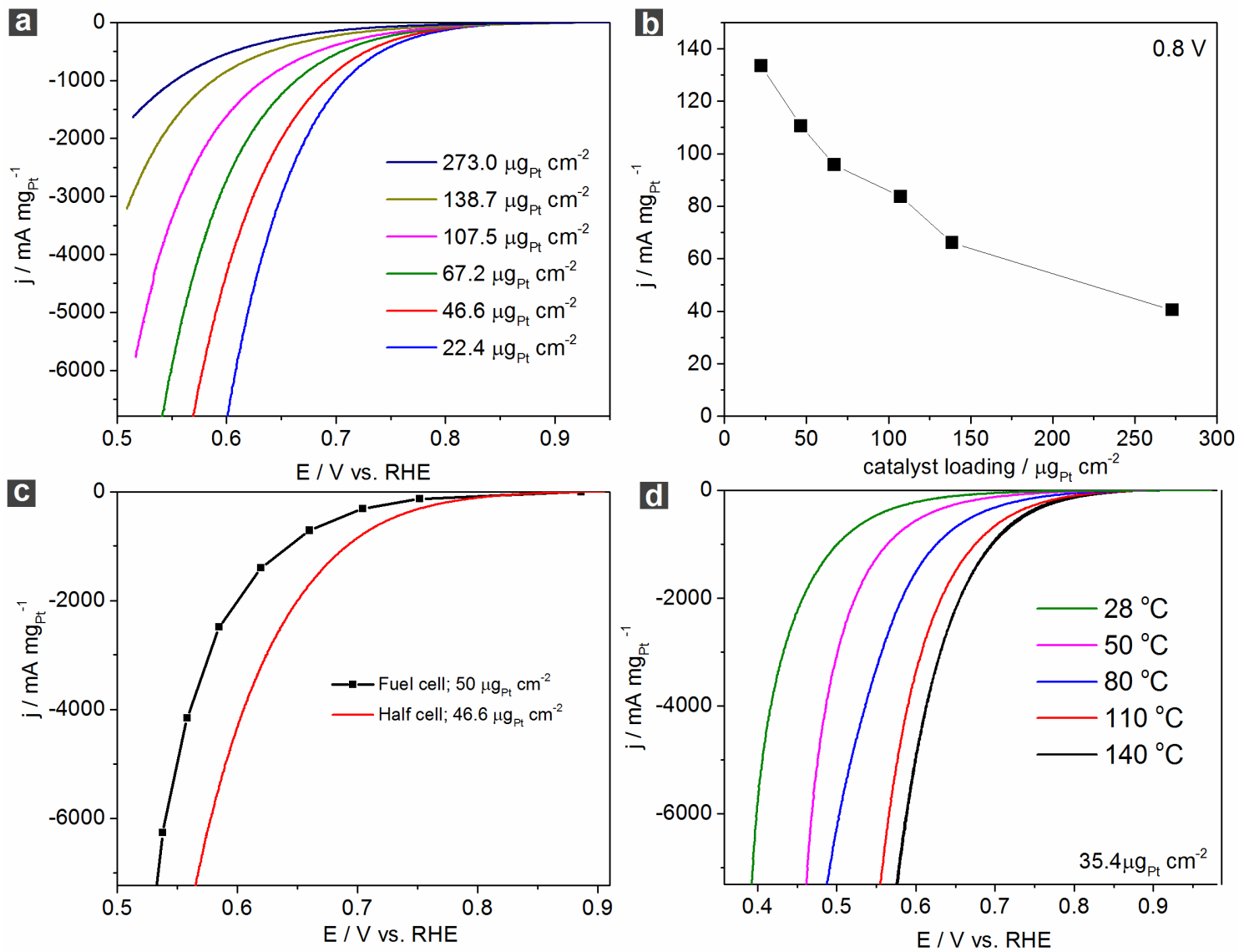

Figure 4: (a) ORR polarization curves of $20 \mathrm{wt} \% \mathrm{Pt} / \mathrm{C}$ electrodes with different catalyst loadings by half-cell testing in $85 \% \mathrm{H}_{3} \mathrm{PO}_{4}$ at $140{ }^{\circ} \mathrm{C}$. The PTFE content was $10 \mathrm{wt} \%$ in all electrodes. (b) The ORR activities of the electrodes reported in (a) at $0.8 \mathrm{~V}$. (c) Comparison of the fuel cell and half-cell test results of the same catalyst (i.e. $20 \mathrm{wt} \% \mathrm{Pt} / \mathrm{C})$ under similar conditions $\left(85 \% \mathrm{H}_{3} \mathrm{PO}_{4}, 140{ }^{\circ} \mathrm{C}\right.$, $50 \mu \mathrm{g}_{\mathrm{Pt}} \mathrm{cm}^{-2}$ ). (d) ORR polarization curves of an electrode consisting of $35.4 \mu \mathrm{g}_{\mathrm{Pt}} \mathrm{cm}^{-2}$ of $20 \mathrm{wt} \%$ $\mathrm{Pt} / \mathrm{C}$ and $10 \mathrm{wt} \% \mathrm{PTFE}$ at different temperatures.

\section{References}

[1] M.K. Debe, Nature, 486 (2012) 43-51.

[2] M.E. Scofield, H. Liu, S.S. Wong, Chemical Society Reviews, 44 (2015) 5836-5860.

[3] R. Borup, J. Meyers, B. Pivovar, Y.S. Kim, R. Mukundan, N. Garland, D. Myers, M. Wilson, F. Garzon, D. Wood, P. Zelenay, K. More, K. Stroh, T. Zawodzinski, J. Boncella, J.E. McGrath, M. Inaba, K. Miyatake, M. Hori, K. Ota, Z. Ogumi, S. Miyata, A. Nishikata, Z. Siroma, Y. Uchimoto, K. Yasuda, K.-i. Kimijima, N. Iwashita, Chem. Rev., 107 (2007) 3904-3951.

[4] K. Schmidt-Rohr, Q. Chen, Nat. Mater., 7 (2008) 75-83.

[5] K. Broka, P. Ekdunge, J. Appl. Electrochem., 27 (1997) 117-123.

[6] Q. Li, R. He, J.O. Jensen, N.J. Bjerrum, Chem. Mat., 15 (2003) 4896-4915. 
[7] J.O. Jensen, Q. Li, C. Pan, A.P. Vestbø, K. Mortensen, H. Nybo Petersen, C. Lau Sørensen, T. Nedergaard Clausen, J. Schramm, N.J. Bjerrum, International Journal of Hydrogen Energy, 32 (2007) 1567-1571.

[8] Q.F. Li, J.O. Jensen, R.F. Savinell, N.J. Bjerrum, Prog. Polym. Sci., 34 (2009) 449-477.

[9] J. Zhang, Z. Xie, J. Zhang, Y. Tang, C. Song, T. Navessin, Z. Shi, D. Song, H. Wang, D.P. Wilkinson, Z.-S. Liu, S. Holdcroft, Journal of Power Sources, 160 (2006) 872-891.

[10] J. Lobato, P. Canizares, M.A. Rodrigo, J.J. Linares, Electrochimica Acta, 52 (2007) 3910-3920.

[11] J. Lobato, P. Cañizares, M.A. Rodrigo, J.J. Linares, J.A. Aguilar, J. Membr. Sci., 306 (2007) 47-55.

[12] Y. Garsany, O.A. Baturina, K.E. Swider-Lyons, S.S. Kocha, Anal. Chem., 82 (2010) 6321-6328.

[13] K.C. Neyerlin, W.B. Gu, J. Jorne, H.A. Gasteiger, J. Electrochem. Soc., 154 (2007) B631-B635.

[14] K. Shinozaki, J.W. Zack, S. Pylypenko, B.S. Pivovar, S.S. Kocha, J. Electrochem. Soc., 162 (2015) F1384-F1396.

[15] K. Shinozaki, J.W. Zack, R.M. Richards, B.S. Pivovar, S.S. Kocha, J. Electrochem. Soc., 162 (2015) F1144-F1158.

[16] M.B. Stevens, L.J. Enman, A.S. Batchellor, M.R. Cosby, A.E. Vise, C.D.M. Trang, S.W. Boettcher, Chem. Mat., (2016).

[17] U.A. Paulus, T.J. Schmidt, H.A. Gasteiger, R.J. Behm, Journal of Electroanalytical Chemistry, 495 (2001) $134-145$.

[18] J.S. Jirkovsky, M. Halasa, D.J. Schiffrin, Phys. Chem. Chem. Phys., 12 (2010) 8042-8052.

[19] K. Klinedinst, J.A.S. Bett, J. Macdonald, P. Stonehart, Journal of Electroanalytical Chemistry, 57 (1974) $281-289$.

[20] H.A. Gasteiger, N.M. Markovic, P.N. Ross, J. Phys. Chem., 99 (1995) 8290-8301.

[21] K.L. Hsueh, E.R. Gonzalez, S. Srinivasan, D.T. Chin, J. Electrochem. Soc., 131 (1984) 823-828.

[22] J.T. Glass, G.L. Cahen, G.E. Stoner, J. Electrochem. Soc., 136 (1989) 656-660.

[23] M.J. Fleige, G.K.H. Wiberg, M. Arenz, Review of Scientific Instruments, 86 (2015) 064101.

[24] J.C. Huang, R.K. Sen, E. Yeager, J. Electrochem. Soc., 126 (1979) 786-792.

[25] Y.-X. Chen, M.-F. Li, L.-W. Liao, J. Xu, S. Ye, Electrochemistry Communications, 11 (2009) 1434-1436.

[26] H.R. Kunz, G.A. Gruver, J. Electrochem. Soc., 122 (1975) 1279-1287.

[27] B.A. Pinaud, A. Bonakdarpour, L. Daniel, J. Sharman, D.P. Wilkinson, J. Electrochem. Soc., 164 (2017) F321-F327.

[28] G.K.H. Wiberg, M. Fleige, M. Arenz, Review of Scientific Instruments, 86 (2015) 024102.

[29] G.K.H. Wiberg, M.J. Fleige, M. Arenz, Review of Scientific Instruments, 85 (2014) 085105.

[30] C.M. Zalitis, D. Kramer, A.R. Kucernak, Phys. Chem. Chem. Phys., 15 (2013) 4329-4340.

[31] M. Mamlouk, K. Scott, Journal of Power Sources, 196 (2011) 1084-1089.

[32] J. Giner, C. Hunter, J. Electrochem. Soc., 116 (1969) 1124-\&.

[33] Q.F. Li, G. Xiao, H.A. Hjuler, R.W. Berg, N.J. Bjerrum, J. Electrochem. Soc., 141 (1994) 3114-3119.

[34] N.H. Ray, Journal of Non-crystalline Solids, 5 (1970).

[35] D. van der Vliet, D.S. Strmcnik, C. Wang, V.R. Stamenkovic, N.M. Markovic, M.T.M. Koper, Journal of Electroanalytical Chemistry, 647 (2010) 29-34.

[36] H.A. Gasteiger, S.S. Kocha, B. Sompalli, F.T. Wagner, Appl. Catal. B-Environ., 56 (2005) 9-35.

[37] Q. Li, G. Wu, D.A. Cullen, K.L. More, N.H. Mack, H.T. Chung, P. Zelenay, ACS Catalysis, 4 (2014) 3193-3200.

[38] S. Litster, G. McLean, Journal of Power Sources, 130 (2004) 61-76.

[39] X. Cheng, B. Yi, M. Han, J. Zhang, Y. Qiao, J. Yu, Journal of Power Sources, 79 (1999) 75-81.

[40] O.J. Murphy, G.D. Hitchens, D.J. Manko, Journal of Power Sources, 47 (1994) 353-368.

[41] J. Giner, J.M. Parry, S. Smith, M. Turchan, J. Electrochem. Soc., 116 (1969) 1692-1696.

[42] N.M. Markovic, T.J. Schmidt, B.N. Grgur, H.A. Gasteiger, R.J. Behm, P.N. Ross, J. Phys. Chem. B, 103 (1999) 8568-8577.

[43] T. Engl, K.E. Waltar, L. Gubler, T.J. Schmidt, J. Electrochem. Soc., 161 (2014) F500-F505. 